\title{
Cellular transport of anti-inflammatory pro-drugs originated from a herbal formulation of Zingiber cassumunar and Nigella sativa
}

\author{
Prasan Tangyuenyongwatana ${ }^{1}$, Jariya Kowapradit ${ }^{2}$, Praneet Opanasopit ${ }^{2}$ and \\ Wandee Gritsanapan*1
}

Address: ${ }^{1}$ Department of Pharmacognosy, Faculty of Pharmacy, Mahidol University, Bangkok 10400, Thailand and ${ }^{2}$ Department of Pharmaceutical Technology, Faculty of Pharmacy, Silpakorn University, Nakhon Pathom 73000, Thailand

Email: Prasan Tangyuenyongwatana - prtang2000@yahoo.com; Jariya Kowapradit - neoy023@gmail.com;

Praneet Opanasopit - Praneet@email.pharm.su.ac.th; Wandee Gritsanapan* - pywgs@mahidol.ac.th

* Corresponding author

Published: 25 September 2009

Chinese Medicine 2009, 4:19 doi:10.1186/1749-8546-4-19

This article is available from: http://www.cmjournal.org/content/4/I/19

(C) 2009 Tangyuenyongwatana et al; licensee BioMed Central Ltd.

This is an Open Access article distributed under the terms of the Creative Commons Attribution License (http://creativecommons.org/licenses/by/2.0), which permits unrestricted use, distribution, and reproduction in any medium, provided the original work is properly cited.
Received: 7 December 2008

Accepted: 25 September 2009

\begin{abstract}
Background: The rhizome of Zingiber cassumunar and the seed of Nigella sativa are two ingredients in Thai traditional medicine to relieve dysmenorrhea and adjust the menstrual cycle. Mixture of these two herbs produces three esters, namely $(E)-4$-(3,4-dimethoxyphenyl)but-3-en-I-yl linoleate (I), (E)-4-(3,4-dimethoxyphenyl)but-3-en- I-yl oleate (2) and (E)-4-(3,4-dimethoxyphenyl)but-3-en$\mathrm{I}$-yl palmitate (3). The aim of this study is to examine in vitro absorption of these esters and evaluate their transport across the membrane.
\end{abstract}

Methods: In vitro transport of these three esters was observed in Caco-2 cell monolayers. The ester compounds I, 2 and 3 at a concentration of $10 \mu \mathrm{M}$ were hydrolyzed by porcine liver esterase.

Results: All esters transported across the Caco- 2 cell without enzymatic hydrolysis. The apparent permeability coefficients $P_{\text {app }}$ of compound I at $53 \mu \mathrm{M}$ and $106 \mu \mathrm{M}$ were $13.94(0.60) \times 10^{-6}$ and $14.33(0.17) \times 10^{-6} \mathrm{~cm} / \mathrm{s}$ respectively, while those of compound 2 were $9.45(0.29) \times 10^{-6}$ and 10.08 $(0.32) \times 10^{-6} \mathrm{~cm} / \mathrm{s}$, respectively. $P_{\text {app }}$ values of compound 3 were $7.48(0.31) \times 10^{-6} \mathrm{~cm} / \mathrm{s}$ at $53 \mu \mathrm{M}$ and $8.60(0.55) \times 10^{-6} \mathrm{~cm} / \mathrm{s}$ at $106 \mu \mathrm{M} . P_{\text {app }}$ values of the parent compound (compound D), i.e. $(E)$ 4-(3,4-dimethoxyphenyl)but-3-en- I-ol were $8.53(0.83) \times 10^{-6} \mathrm{~cm} / \mathrm{s}$ at $53 \mu \mathrm{M}$ and $16.38(0.6 \mathrm{I}) \times 10^{-}$ ${ }^{6} \mathrm{~cm} / \mathrm{s}$ at $106 \mu \mathrm{M}$. The ester hydrolysis of compounds I, 2 and 3 by porcine liver esterase was monitored by HPLC and the hydrolysis reactions were completed within 10 minutes.

Conclusion: Using the Caco-2 cell monolayer model, the present study finds that compounds $(E)$ 4-(3,4-dimethoxyphenyl)but-3-en-I-yl linoleate (I), (E)-4-(3,4-dimethoxyphenyl)but-3-en-I-yl oleate (2) and (E)-4-(3,4-dimethoxyphenyl)but-3-en-I-yl palmitate (3) originated from Prasaplai preparation (a Thai herbal formula) may be transported through a facilitated mechanism and serve as pro-drugs to increase the compound $\mathrm{D}$ level in the blood. 


\section{Background}

Zingiber cassumunar (Z. cassumunar, cassumunar ginger) and Nigella sativa (N. sativa, black cumin) are widely used as single herbs or as components of herbal formulae in Asian traditional medicines. One of the compounds isolated from $Z$. cassumunar, (E)-4-(3,4-dimethoxyphenyl)but-3-en-1-ol is named compound $\mathrm{D}[1,2]$. In a carrageenan-induced rat paw edema model, compound D from a hexane extract of $Z$. cassumunar showed a potent inhibitory effect on edema formation [2]. Compound D also demonstrated a dose dependent uterine relaxant effect in uterus of non-pregnant rat [3].

Three artificial fatty acid esters were found in the mixture of dry powders of $Z$. cassumunar rhizome and $N$. sativa seeds $[4,5]$ which are main constituents of the Prasaplai preparation, a traditional Thai herbal formula to treat dysmenorrheal and adjusting the menstrual cycle [6]. The three artificial fatty acid esters were identified as (E)-4(3,4-dimethoxy-phenyl)but-3-en-1-yl linoleate (1), (E)-4(3,4-dimethoxy-phenyl)but-3-en-1-yl oleate $(2)$ and $(E)$ 4-(3,4-dimethoxy-phenyl)but-3-en-1-yl palmitate (3) (Figure 1). Reaction between compound D in Z. cassumunar and linoleic, oleic and palmetic acids from N. sativa generates these three artificial compounds which are active against Mycobacterium tuberculosis $\mathrm{H}_{37} \mathrm{Ra}$. Minimal inhibitory concentration of compounds 1 and 3 is $200 \mu \mathrm{g} /$ $\mathrm{ml}$ and that of compound 2 is $100 \mu \mathrm{g} / \mathrm{ml}$. When tested for anti-herpes simplex virus (HSV-1) activities in human vero cell line, compound 2 was active at $\mathrm{IC}_{50}$ of $42.6 \mu \mathrm{g} /$
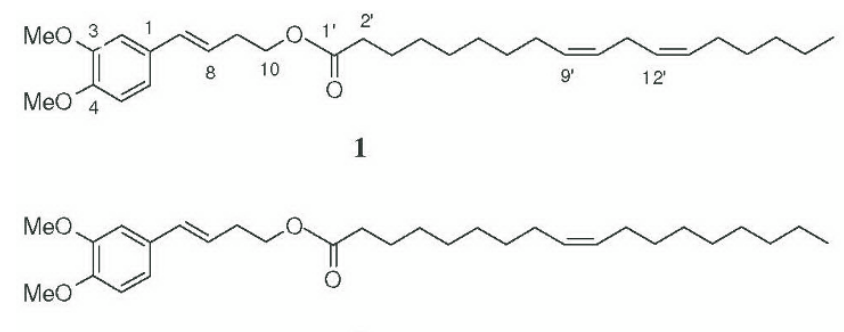

2

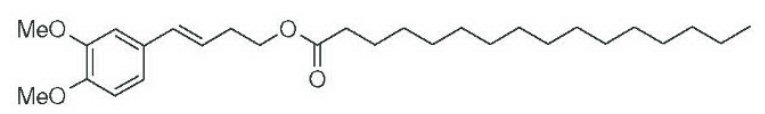

3

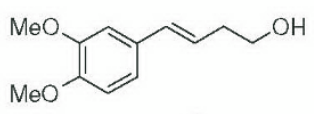

4

Figure I

Chemical structures of compounds I, 2, 3 and D I: compound I; 2: compound 2; 3: compound 3; 4: compound D. ml without cytotoxicity whereas compound 3 was cytotoxic at $\mathrm{IC}_{50}$ of $38 \mu \mathrm{g} / \mathrm{ml}$ [7].

We are interested in the role of these fatty acid esters in the Prasaplai preparation. One hypothesis is that the fatty acid esters may act as pro-drugs in order to increase the absorption [8] of the parent compound, i.e. compound D. The present study aims to investigate the absorption of these fatty acid esters in an in vitro model and predict their transport across the human intestinal membrane.

As a cell monolayer model that imitates in vivo intestinal epithelium in human Caco-2 cell line, a human colon adrenocarcinoma grows rapidly into confluent monolayer that exhibits several characteristics of differentiated epithelial cells. Permeation characteristic of compounds especially drugs across Caco- 2 cell monolayer correlates with their human intestinal mucosa permeation characteristics [9]. We used this cell culture model to assess the intestinal permeability of tested compounds.

\section{Methods \\ Materials}

Compounds 1, 2, 3 and D were synthesized and purified (over 95\%) in our laboratory [5]. The Caco-2 cell line was obtained from the American Type Culture Collection (ATCC HTB-37). Dulbecco's modified Eagle's medium (DMEM), trypsin-EDTA, L-glutamine, non-essential amino acid, penicillin-streptomycin antibiotics and fetal bovine serum (FBS) were obtained from GIBCO-Invitrogen (USA). Transwell (6-well plates) cell culture chambers inserted with $3.0 \mu \mathrm{m}$ pore size were purchased from Corning Life Sciences (USA). Esterase enzyme was obtained from Sigma (USA). All other chemicals were of cell culture and molecular biology grade from Sigma (USA).

\section{Analytical methods}

We used a high performance liquid chromatography (HPLC) system consisting of a Knauer pump K-1001 and a Knauer Photometer K-2600 detector (Knauer, Germany) with detection at $254 \mathrm{~nm}$. The separation was performed on a Kromasil $5 \mu \mathrm{m} 100 \mathrm{AC}_{18}, 250 \times 4 \mathrm{~mm}$ column (Phenomenex, USA). Flow rate was $0.8 \mathrm{ml}$ per minute and the solvent system was a gradient elution of $1 \%$ acetic acid in water and acetonitrile $\left(\mathrm{CH}_{3} \mathrm{CN}\right)$ at $85: 15,70: 30,55: 45$, 50:50, 30:70, 15:85, 0:100 and 0:100 at 0, 8, 25, 30, 55, 65,80 and 110 minutes, respectively. Compounds 1,2 and 3 were separated by non-polar stationary phase (octadecylsilane, ODS) eluted with $100 \% \mathrm{CH}_{3} \mathrm{CN}$ at the last stage of the gradient elution.

As the fatty acid esters were not stable in transported medium, the UV spectroscopy was used to monitor the amounts of compounds 1, 2, 3 and D. Spectrophotometry analysis was performed on a Helios alpha UV-Vis spectro- 
photometer (Thermo Scientific, USA). The maximum wavelength $\left(\lambda_{\max }\right)$ was obtained at $228 \mathrm{~nm}$. Standards of each compound were freshly prepared at the concentration range of $0.62-3.73 \mu \mathrm{g} / \mathrm{mL}$. Validations were performed by five replicates of intra-day and three replicates of inter-day. The linear correlation coefficients $(r)$ between the UV-absorption and the concentrations of all compounds were in the range of 0.9993-0.9996 (compound $1: \mathrm{Y}=109.67 \mathrm{X}+0.031, r=0.9994$; compound $2: \mathrm{Y}$ $=109.44 \mathrm{X}+0.028, r=0.9995$; compound $3: \mathrm{Y}=$ $118.58 \mathrm{X}+0.049, \quad r=0.9996 ;$ compound $\mathrm{D}: \mathrm{Y}=$ $169.72 \mathrm{X}+0.058, r=0.9993)$.

\section{Cell culture}

Caco-2 cells were maintained in a DMEM at pH7.4, supplemented with $10 \%$ fetal bovine serum, $2 \mathrm{mM} \mathrm{L-}$ glutamine, $1 \%$ non-essential amino acid solution and $0.1 \%$ penicillin-streptomycin solution in a humidified atmosphere $\left(5 \% \mathrm{CO}_{2}, 95 \%\right.$ air, at $\left.37^{\circ} \mathrm{C}\right)$. Cells were grown until $60-70 \%$ confluence. Cells from passages 20 40 were used for all experiments. Cells were seeded on tissue culture polycarbonate membrane filters (pore size: 3.0 $\mu \mathrm{m}$ ) in 6-well Transwell plates (Corning, USA) at a seeding density of $2 \times 10^{4} \mathrm{cells} / \mathrm{cm}^{2}$. Culture medium was added to both the donor and the acceptor compartments. Medium was changed every two days. Cells were left to differentiate for 15-21 days after seeding with monitoring of trans-epithelial electrical resistance (TEER) values with a Millicell electrical resistance system (Millipore, USA) and the value should be higher than $600 \Omega . \mathrm{cm}^{2}$.

\section{Chemical hydrolysis study of the compounds in transport medium}

Solution of compound 1, 2 and 3 at $53 \mu \mathrm{M}$ and $106 \mu \mathrm{M}$ were prepared in Hank's balanced salt solution (HBSS) at pH7.4. All solutions were kept at $4{ }^{\circ} \mathrm{C}$ for 96 hours and each solution was then analyzed by HPLC at $12,24,48$, 72 and 96 hours to determine the hydrolysis product.

\section{Transport studies}

Transport experiment across the Caco- 2 cell monolayers at pH7.4 was performed. Caco-2 cell monolayers in Transwell (6-well) plates were used for transport studies when they were differentiated and the monolayer was intact, as checked by measuring TEER. Prior to the experiment, the cells were washed twice with phosphate buffered saline (PBS) and pre-equilibrated for one hour with HBSS buffered with $30 \mathrm{mM} \mathrm{n}$-(2-hydroxyethyl) piperazine-n-(2-ethanosulfonic acid) (HEPES) at pH7.4. After medium was removed, the cells were treated with sample solutions (concentrations of $53 \mu \mathrm{M}$ and $106 \mu \mathrm{M}$ in HBSS at pH7.4) in an apical compartment. Samples $(1 \mathrm{~mL})$ were taken under sink conditions at 0, 5, 20, 40, 60, 80 and 100 minutes from the basolateral side and replaced with an equal volume of fresh HBSS solution. The amount of the com- pounds from the basolateral side was determined on a UV-spectrophotometer (Thermo Scientific, USA) at 228 $\mathrm{nm}$. Results were expressed as cumulative transport as a function of time. Apparent permeability coefficient was calculated according to the following equation:

$$
P_{a p p}=(d Q / d t) \times\left(1 / A C_{o}\right)
$$

where $P_{\text {app }}$ is the apparent permeability coefficient $(\mathrm{cm} / \mathrm{s})$, $\mathrm{dQ} / \mathrm{d} t(\mu \mathrm{g} / \mathrm{s})$ is the rate of appearance of sample on the basolateral side, $A$ is the surface area of the monolayer $\left(\mathrm{cm}^{2}\right)$ and $C_{0}(\mu \mathrm{g} / \mathrm{mL})$ is the initial drug concentration in the donor compartment. All rate constants were obtained from the permeation profiles of each compound. Statistical significance was evaluated with one-way analysis of variance (one-way ANOVA). A value of $P<0.05$ was considered statistically significant.

\section{Enzyme hydrolysis study of the compounds}

Compound 1 ( $2 \mathrm{~mL}, 10 \mu \mathrm{M}$ solution) was pre-incubated at $37^{\circ} \mathrm{C}$ and $200 \mu \mathrm{L}$ of esterase enzyme (porcrine liver, 750 units) was added. Samples ( $200 \mu \mathrm{L}$ each) were taken at 5,10,20, 30 and 60 minutes and added to $200 \mu \mathrm{L}$ of methanol. Mixtures were vortexed to stop enzymatic activity. Samples were then centrifuged for five minutes at $14,000 \times \mathrm{g}$ (Lab Essentials, USA). Supernatant was injected to the HPLC system for the determination of ester pro-drugs and compound $\mathrm{D}$. This procedure was repeated for compounds 2 and 3.

\section{Results}

Compounds 1, 2 and 3 were prepared in transport medium at concentrations of $53 \mu \mathrm{M}$ and $106 \mu \mathrm{M}$ and stored at $4{ }^{\circ} \mathrm{C}$ for 96 hours. The samples were collected every 12 hours and analyzed on the HPLC system. Compound D was detected by the HPLC after 24 hours. As the fatty acid esters were not stable long enough in the transported medium, the HPLC analysis must be carried out in a short period of time. A UV absorption method was used to measure the amount of transported compounds in this experiment. The UV analysis was designed and validated in the range of $0.62-3.73 \mu \mathrm{g} / \mathrm{mL}$ and the linear correlations $(r)$ of all compounds were shown in the range of 0.9993-0.9996. All samples were analyzed and finished within several hours.

Rate of transport of each compound was estimated from the slope of the linear portion of a plot of cumulative amount. The apparent permeability coefficients $\left(P_{\text {app }}\right)$ for these compounds were calculated from the experimental data which were determined from the apical to basolateral side (Table 1, Figure 2).

The hydrolysis of the fatty acid esters was confirmed by an in vitro assay with esterase enzyme from porcine liver. 
Table I: Apparent permeability coefficient $\left(P_{\text {app }}\right)$ of compounds $1,2,3$ and $D(n=3)$

\begin{tabular}{llll}
\hline Compound & $\begin{array}{l}* \boldsymbol{P}_{\text {app }} \text { at } 53 \mu \mathbf{M} \\
\left(10^{-6} \mathbf{c m} / \mathbf{s}\right)\end{array}$ & $\begin{array}{l}* \boldsymbol{P}_{\text {app }} \text { at } \mathbf{1 0 6} \mu \mathbf{M} \\
\left(10^{-6} \mathbf{c m} / \mathbf{s}\right)\end{array}$ & $\begin{array}{l}\boldsymbol{P} \\
\text { Value }\end{array}$ \\
\hline Compound I & $13.94(0.60)$ & $14.33(0.17)$ & 0.364 \\
Compound 2 & $9.45(0.29)$ & $10.08(0.32)$ & 0.146 \\
Compound 3 & $7.48(0.31)^{* *}$ & $8.60(0.55)^{* *}$ & 0.014 \\
Compound D & $8.53(0.83)^{* *}$ & $16.38(0.61)^{* *}$ & 0.001
\end{tabular}

*expressed as mean (SD), $\mathrm{n}=3$

$* * P<0.05$, significantly different between these two concentrations.

After the esters were mixed with esterase enzyme and incubated at $37^{\circ} \mathrm{C}$, the hydrolysis reaction was completed within 10 minutes and compound $\mathrm{D}$ was detected.

The apparent permeability coefficient $\left(P_{\text {app }}\right)$ of compounds 1 and 2 at $53 \mu \mathrm{M}$ showed no significant difference compared with those at concentration of $106 \mu \mathrm{M}$ (compound $1: P=0.364$; compound $2: P=0.146) . P_{\text {app }}$ of compound $\mathrm{D}$ at $106 \mu \mathrm{M}$ was significantly different from that at $53 \mu \mathrm{M}(P=0.001)$. Compound D had $P_{\text {app }}$ values close

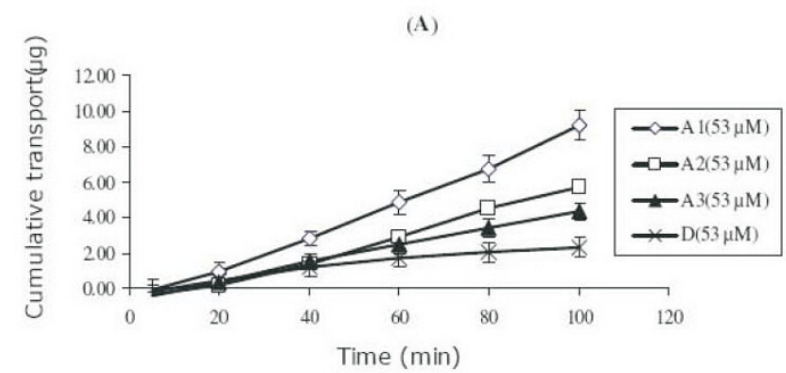

(B)

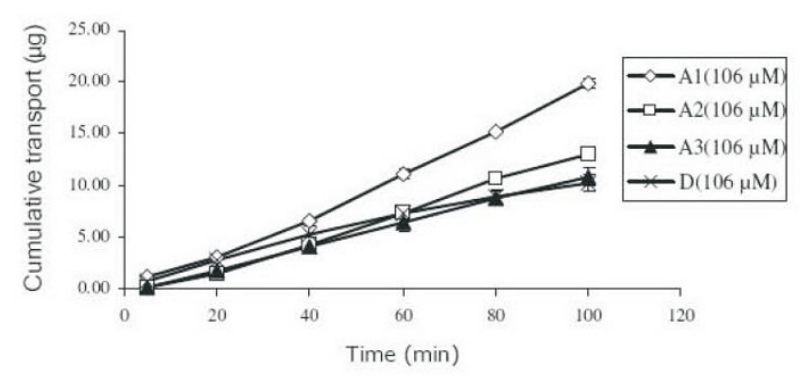

Figure 2

Cumulative amounts of the fatty acid esters and compound D. (A) At $53 \mu \mathrm{M}$ in the apical to basolateral direction, compound I (AI) showed highest cumulative transport over other two fatty acid ester (A2 and $A 3)$ and compound D. (B) At $106 \mu \mathrm{M}$ in the apical to basolateral direction, compound I (AI) showed higher cumulative transport over other two fatty acid ester (A2 and $A 3$ ) while compound $\mathrm{D}$ had cumulative transport close to compound 3 (A3). Al: compound I; A2: compound 2; A3: compound 3; D: compound D. to those of compounds 2 and 3 at $53 \mu \mathrm{M}$, while $P_{\text {app }}$ values of compounds D, 1, 2 and 3 differed significantly $(P=$ 0.001 ) at $106 \mu \mathrm{M}$.

The lipophilicity of these compounds can be estimated with software ACD/labs version 11.03 (Advanced Chemistry Development, USA). The log P of compounds 1, 2, and 3 were $10.13(0.42), 10.65(0.40)$ and $10.11(0.39)$ respectively.

\section{Discussion}

The results suggest that the absorption mechanism of compounds 1 and 2 was not dependent on the concentrations of the fatty acid esters. Facilitated transport may be the mechanism. Compound D seemed to follow a concentration dependent passive diffusion mechanism.

$P_{\text {app }}$ values ranged from $7.47 \times 10^{-6}$ to $16.38 \times 10^{-6} \mathrm{~cm} / \mathrm{s}$ in an apical to basolateral direction. According to a previous study [10], $P_{\text {app }}$ value in Caco- 2 cells higher than $1 \times 10^{-}$ ${ }^{6} \mathrm{~cm} / \mathrm{s}$ is associated with efficient intestinal absorption in human. At $53 \mu \mathrm{M}$, compound 1 showed the highest transport across the Caco- 2 cell monolayers among all compounds. Compound 2 demonstrated higher permeability than that of compound D $(P=0.146)$. At $106 \mu \mathrm{M}$, compound 1 showed higher transport across Caco- 2 cell than that of compounds 2 and 3 but lower transport than that of compound D.

These lipophilicity values do not correlate well to the transport results. More valid estimation of lipophilicity of the compounds may come from analysis of retention time of a reverse phase HPLC chromatogram [11,12] (Figure $3)$. The retention times $\left(t_{r}\right)$ of compounds 1, 2 and 3 were 92.4, 101.0 and 102.0 minutes, respectively. Polarity of compound 1 was higher than that of compounds 2 and 3.

The hydrolysis of compound 1, 2 and 3 did not occur during the transport across Caco- 2 cell monolayers. This may be due to the unusual long chain fatty acid structure of these compounds and other factors such as the duration of the time contact with the enzyme during transport. However the hydrolysis of the ester linkage in these compounds may occur in the blood circulation or in the liver because these compounds can be hydrolyzed by porcine liver esterase within in ten minutes.

\section{Conclusion}

Using the Caco-2 cell monolayer model, the present study finds that compounds (E)-4-(3,4-dimethoxy-phenyl)but3-en-1-yl linoleate (1), (E)-4-(3,4-dimethoxy-phenyl)but3-en-1-yl oleate (2) and (E)-4-(3,4-dimethoxy-phenyl)but-3-en-1-yl palmitate (3) originated from the Prasaplai preparation (a Thai herbal formula) may be 


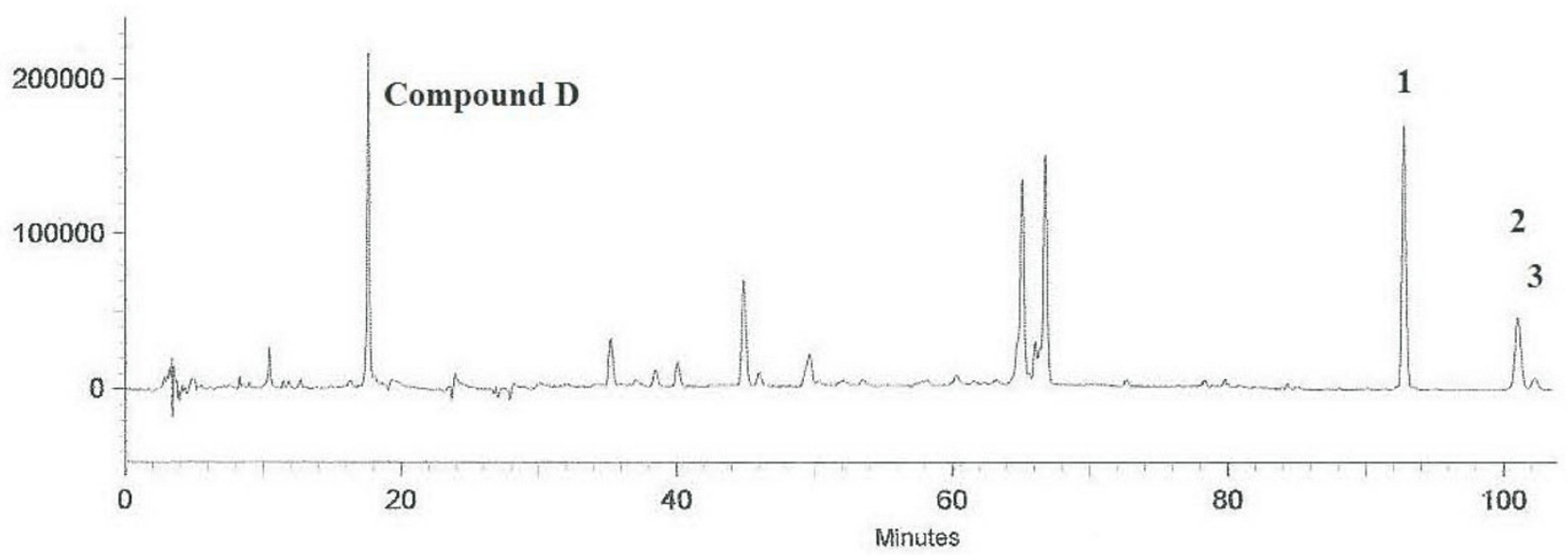

Figure 3

HPLC chromatograms of the mixture of Z. cassumunar and N. sativa. I: compound I; 2: compound 2; 3: compound 3.

transported through a facilitated mechanism and serve as pro-drugs to increase the compound D level in the blood.

\section{Abbreviations}

HSV-1: herpes simplex virus-1; DMEM: Dulbecco's modified Eagle's medium; FBS: fetal bovine serum; TEER: transepithelial electrical resistance; HBSS: Hank's balanced salt solution; HEPES: n-(2-hydroxyethyl) piperazine-n-(2-ethanosulfonic acid); PBS: phosphate buffered saline; $P_{\text {app }}$ : apparent permeability coefficient; ODS: octadecylsilane.

\section{Competing interests}

The authors declare that they have no competing interests.

\section{Authors' contributions}

PT and WG conceived the study design, synthesized the compounds 1, 2, 3 and D, performed HPLC and UV analysis, and drafted the manuscript. JK and PO designed and performed the Caco-2 cell experiment and helped analyze the data. All authors read and approved the final version of the manuscript.

\section{References}

I. Amatayakul T, Cannon JR, Dampawan P, Dechatiwong T, Giles RG, Huntrakul C, Kusamran K, Mokkhasamit M, Raston CL, Reutrakul V, White $\mathrm{AH}$ : Chemistry and crystal structures of some constituents of Zingiber cassumuar. Aust J Chem 1979, 32:7I-88.

2. Panthong A, Kanjanapothi D, Niwatananun V, Tuntiwachwuttikul P, Reutrakul V: Anti-inflammatory activity of compounds isolated from Zingiber cassumunar. Planta Med 1990, 56:655.

3. Kanjanapothi D, Soparat P, Panthong A, Tuntiwachwuttikul P, Reutrakul V: A uterine relaxant compound from Zingiber cassumunar. Planta Med 1987, 53:329-332.

4. Nualkaew S, Gritsanapan W, Petereit F, Nahrstedt A: New fatty acid esters originate during storage by the interaction of components in Prasaplai, a Thai traditional medicine. Planta Med 2004, 70: I243-1246.
5. Tangyuenyongwatana P, Gritsanapan W: A study on artifacts formation in the Thai traditional medicine Prasaplai. Planta Med 2008, 74: I 403-I 405.

6. Poomchusri NT: Ayurvedic Study 2nd edition. Bangkok: Promjakkanpimp; 1973.

7. Tangyuenyongwatana P, Gritsanapan W: Biological evaluations of fatty acid esters originated during storage of Prasaplai, a Thai traditional medicine. Nat Prod Res 2007, 21 :990-997.

8. Hostetler KY, Parker S, Sridhar CN, Martin MJ, Li JL, Stuhmiller LM, Vanwijk GM, van den Bosch H, Gardner MJ, Aldern KA, Richman DD: Acyclovir diphosphate dimyristoylglycerol: a phospholipid prodrug with activity against acyclovir-resistant herpes simplex virus. Proc Natl Acad Sci 1993, 90: 11835.

9. Yamashita S, Furubayashi T, Kataoka M, Sakane T, Sezaki H, Tokuda $\mathrm{H}$ : Optimized conditions for prediction of intestinal drug permeability using Caco-2 cells. Eur J Pharm Sci 2000, 10:195-204.

10. Artursson $\mathrm{P}, \mathrm{Karlsson} \mathrm{J}$ : Correlation between oral drug absorption in humans and apparent drug permeability coefficients in human intestinal epithelial (Caco-2) cells. Biochem Biophys Res Commun 199|, 175:880-885.

II. Lambert WJ: Modeling oil-water partitioning and membrane permeation. using reversed-phase chromatography. J Chromatogr A 1993, 656:469-484.

12. Dorsey J, Khaledi M: Hydrophobicity estimation by reversedphase liquid chromatography. J Chromatogr A 1993, 656:485-499.

Publish with BioMed Central and every scientist can read your work free of charge

"BioMed Central will be the most significant development for disseminating the results of biomedical research in our lifetime. "

Sir Paul Nurse, Cancer Research UK

Your research papers will be:

- available free of charge to the entire biomedical community

- peer reviewed and published immediately upon acceptance

- cited in PubMed and archived on PubMed Central

- yours - you keep the copyright
BioMedcentral 